\title{
The Correlation Relationship between Fiscal Policy and Economic Growth Case of Albania
}

\author{
Rudina Qurku (Feruni), Phd \\ Lecture at Mediterranean University of Albania \\ rudinaqurku@yahoo.com \\ Arta Asllani, MSc \\ Economist at Albanian Business Transparency (www.abt.al) \\ arta.asllani@yahoo.com
}

Doi:10.5901/mjss.2014.v5n13p322

\begin{abstract}
Fiscal policies are important predictors of economic developments. Often government decisions on spending and taxation play an important role in speeding up or slowing economic growth. Fiscal policy in Albania has been under continuous observation thorough reform of spending and tax collection system. Fiscal policy has always been an issue of interest to policymakers in Albania because of its effects on economic growth, prices and interest rates. This paper analyzes the effects of fiscal policy on economic growth in a small country with an open economy, in developing and transition system still unfinished as Albania. The purpose of this paper is to highlight how public activity through taxation and spending policies has served to stimulate economic growth. To achieve his goal, this paper presents a broad overview of theoretical viewpoints and empirical studies focused on this issue. Correlation used and descriptive analysis will reflect the link economic growth- fiscal policy for Albania. It will also analyze the changes in the legislation on taxation and tax reforms after years of transition and their impact on economic growth.
\end{abstract}

\section{Introduction}

Contemporary macroeconomic literature has emphasized fiscal policy objectives, both for the short term, but also in the long term. In the short term, fiscal policy can be used to control the production cycle, as well as to stabilize the volatility of macro indicators, what is the same short-term impact of monetary policy. In the long run, fiscal policy and the financial means of debt can affect demand and aggregate supply.

Taxes make allocation of resources from the private sector to the public. The impact of the public sector in the economy is of particular interest in countries in transition. The role of the state in these countries goes in both directions: on the one hand it is subject of reforms to adapt to the new structure of the economy and on the other hand affects the creation of a positive climate for economic reforms and making other comprehensive reforms to accelerate the process of transition.

Taxes, no matter how necassary they are, stifle private decision, create a distorted allocation of resources and create excessive tax burden. Sometimes you might think that these sprains caused by taxation reflect in economic performance and could slow economic growth. Tax systems can distort private decision for two reasons: Firstly can get more resources from the private sector (tax rates), and secondly can provide income in a less efficient way (tax structure). Often the negative effect of taxes can be derived from what the government decides to tax. The overall level of taxation reflects society's choice of the size of the public sector, while the tax structure represents mostly a tool to realize this choice. Governments could consider changing the tax structure to minimize the negative effects on growth, keeping unchanged the level of public goods and services.

Since the gradual orientation towards a market economy in the early 90 s, the Albanian government had intended to achieve fiscal consolidation through reduction of the budget deficit and public debt. Important changes are those that have occurred over the last decade with the adoption of new fiscal package. Some of these changes were intended to encourage incentives to business and at the same time enable the income tax. Such reforms consisted in passing progressive tax system, in that the flat tax on personal income tax and profit tax, and elimination of exemptions and facilities of the old tax system. Also, facilities for custom duties, performed as a result of trade liberalization. Other changes were also at the level of national taxes, local, excise, social insurance contributions from $42.5 \%$ to $24.5 \%$, reducing the small business tax to $1.5 \%$ from $4 \%$, as well as lowering the threshold for VAT registration. Regarding 
public spending, they have had a downward trend as a result of the government's objective to create more funds for strategic capital expenditures.

State activity or public sector has changed over time, by adapting the trajectory of economic development. Given the political and economic developments over the years and the current situation for Albania can say that besides fiscal policy, an important role in economic growth plays quality of governance and institutions, specifically referring to the judiciary, drafting and adoption of the legal framework, corruption, policy stability, regulatory quality and firms possess information about them, the time spent in the offices of private-public employees, the number of procedures for opening new businesses, giving bribes to public officials, lobbying ect. The aim of fiscal policy, mainly in countries in transition is to achieve fiscal consolidation by keeping the budget deficit levels checked. The best way to achieve this consolidation is to reduce spending moderately, but without forgotten the priority sectors. However, the level of expenditure by those countries often is induced by their ability to collect as much tax revenue by increasing the taxable base and reducing tax rates, and other phenomena that impact negatively on it.

Economic theory provides an explanation for a negative relationship between taxes and economic growth. But, on the other hand, the development of appropriate fiscal instruments can lead to sustainable economic growth and continued. But, how have affected the changes in the fiscal policy in Albania? How is the connection economic growth fiscal policy for this country? This material focuses in the way fiscal policy developed in our country have affected longterm growth rate.

\section{Literature Review}

Does the composition of expenditure and revenue affect the long run growth rate? According to the neoclassical growth models of Solow and Swan (1956) the answer is largely "no". It attempts to explain long-run economic growth by looking at productivity, capital accumulation, population growth, and technological progress. By contrast, endogenous growth theory holds that investment in human capital, innovation, and knowledge are significant contributors to economic growth. The endogenous growth theory primarily holds that the long run growth rate of an economy depends on policy measures. The initial research was based on the work of Kenneth Arrow (1962), Hirofumi Uzawa (1965), and Miguel

Sidrauski (1967), Paul Romer (1986),Lucas (1988), and Rebelo (1991).

Modern growth theory comprises at least three competing strands. The neoclassical theory of economic growth, based focuses in the inputs of physical and human capital into the production process, and on technological advances, as the determinants of economic performance. Alternative explanations for growth are based on geographical factors. Jeffrey Sachs (2001), for example, argues that locational factors such as a temperate climate and access to markets are the keys to growth. The institutional approach characterized by Douglass North (1990) emphasizes the importance of market institutions as the foundation for economic prosperity. Obviously, any discussion of the importance of tax policy on economic growth falls within this institutional approach. It is important to note that these three explanations for growth are not logically inconsistent with each other, so all might play a role, and any empirical examination of economic growth must attempt to control for all of these factors.

A number of studies have explored the impact of taxes on state economic growth. If the theory is reasonably clear, however, the empirical evidence is not. As Stokey and Rebelo (1995) state, "recent estimates of the potential growth effects of tax reform vary wildly, ranging from zero to eight percentage points". Anyway, most, but not all, of these studies find evidence of a negative effect of taxes on various measures of state economic performance. The relationship between the fiscal policy stance and growth will differ across countries depending on their initial fiscal conditions. This also has important implications for the econometric specifications used to link fiscal policy and growth.

Tax reforms are sometimes touted as having strong macroeconomic growth effects (Eric Engen and Jonathan Skinner). Their results suggest modest effects, on the order of 0.2 to 0.3 percentage point differences in growth rates in response to a major tax reform. Nevertheless, even such small effects can have a large cumulative impact on living standards.

The report of OECD (2010) investigates how tax structures can best be designed to support GDP per capita growth. It suggests shifting part of the tax burden from income to consumption and residential property and a greater role for environmental taxes and fees.

Tax revenue may be a possible source to correct the deficit which reduces economic growth and social welfare. The empirical analysis of this study shows that changes in tax rate may have permanent effects on output, but will have only temporary effects on its growth rate in selected Asian Economies. This implies that an increase in the tax rate has permanently reduce the level of output per capita, but have no permanent effect on growth rate (Ihtsham ul Haq Padda and Naeem Akram). 
Most recently, presidential candidate Robert Dole proposed a 15 percent across-the-board income tax cut coupled with a halving of the tax on capital gains, with a predicted increase in gross domestic product (GDP) growth rates from about 2.5 to 3.5 percentage points.

Adam and Bevan in their study suggest(2004) a statistically significant non-linearity in the impact of the budget deficit on growth at around 1.5\% of GDP. Also the analysis suggests that while the impacts on growth of taxes and grants are reasonably straightforward, the impact of deficit is likely to be complex, depending on the financing mix and the outstanding debt stock.

Others have questioned whether tax reform would have such beneficial effects on economic growth. If tax cuts fail to produce the projected boost in economic growth, tax revenues could decline, putting upward pressure on the deficit, worsening levels of national saving, and leading to laggard economic growth in the future. One of the primary complications is that economic policies affect economic growth, and economic growth may in turn affect income equality (Clark and Lawrson, 2008). In an economy globalists higher tax rates reduce economic growth of a country due to the relocation of capital abroad, in countries with the most appropriate tax rate.

\section{Evidence from Albania}

In the late 90 's and over the last decade, policies economic implemented in Albania have been aimed at safeguarding macroeconomic stability, reducing poverty and creatingfavorable conditions for a non-inflationary economic growth, as and achieve fiscal consolidation by reducing deficit budget and public debt. Public finances suffered reformations substantial and ongoing, aiming at reducing government spending and increase revenues. In addition, tax revenues suffered large reductions as a result of lower gradual customs duties due to free trade agreements, under the Stabilisation and Association Agreement with EU, CEFTA and membership in the World Trade. This was followed by an increase in local tax and national excise tax , reductions in contributions social security and health of the business tax small, and changes the threshold for registration of Tax Value Added Tax (VAT ). Changes in tax legislation was finalized with the elimination of all exemptions and fiscal incentives under the old tax system , the adoption of the flat tax from $10 \%$ in 2007 and reduce the corporate tax to $10 \%$ in 2008. The following graph shows the performance of tax revenues and expenditures over the years for Albania.

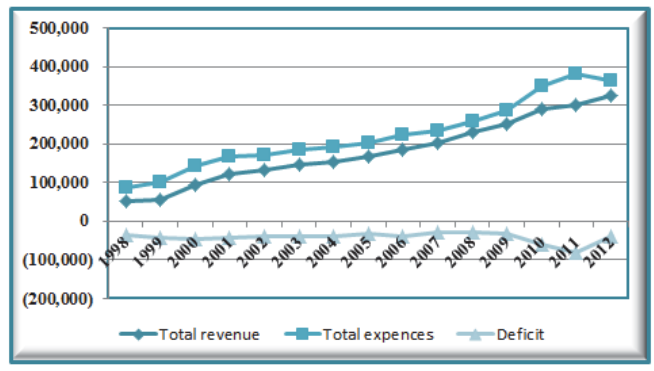

Source: Ministry of Finance

As we have mentioned, the aim of this paper is to note the correlation that exists between fiscal policy, represented by tax revenues (taxes and customs duties, local taxes and contributions) and tax expense growth. The table below shows the correlation that exists between these variables. The data belong to a 15-year period (1998-2012). Results in this table show that between fiscal policy and economic growth in our country there is a negative relationship, and this relationship

\begin{tabular}{lcccccc|} 
Correlation between indicators & $\begin{array}{c}\text { Taxs and } \\
\text { customs }\end{array}$ & $\begin{array}{c}\text { Local } \\
\text { Goverment }\end{array}$ & Contributions & $\begin{array}{c}\text { Total tax } \\
\text { revenues }\end{array}$ & $\begin{array}{c}\text { Total } \\
\text { expenditures }\end{array}$ & $\begin{array}{c}\text { GDP Growth } \\
\text { (\% Annual) }\end{array}$ \\
\hline Taxs and customs & 1 & 0.856440 & 0.988338 & 0.99884 & 0.96043 & -0.70417 \\
Local Goverment & 0.856440 & 1 & 0.895646 & 0.87806 & 0.72195 & -0.44885 \\
Contributions & 0.988338 & 0.895646 & 1 & 0.99369 & 0.94341 & -0.66167 \\
Total tax revenues & 0.998848 & 0.878069 & 0.993699 & 1 & 0.95289 & -0.68932 \\
Total expenditures & 0.960437 & 0.721959 & 0.943413 & 0.95289 & 1 & -0.68157 \\
GDP Growth (\% ANNUAL) & -0.70417 & -0.448850 & -0.66166 & -0.6893 & -0.6815 & 1 \\
\hline
\end{tabular}

Source: Authors own calculations 
is statistically at average importance. Revenue from taxes and customs have a strong negative relation than other indicators, while local taxes appear to have a lower impact.

Being to analyze the issues related specifically to Albania it was noticed that there is a gap between the quality of the regulatory base, as in fiscal terms, but also in the institutional, their implementation in practice. If we refer to the policy of budgetary revenue tax rates have often been the subject of ongoing reforms to reduce the fiscal load, but little is actually done in terms of revenue administration, despite reforms, computer systems implementation, training of personnel of tax administration etc. According to the Ministry of Finance it is noted a decline in tax revenues due to the impact of the economic slowdown shows that there is a close relation between economic growth and revenue collection and highlights the fact that other factors such as evasion, corruption, the administration did not change significantly.

In the fiscal area, for the case of Albania there are very few studies made. To our knowledge, the relationship PF's economic growth for Albania's case, it is only recently studied in order empirical . In a paper, Mançellari (2011) examines effects of fiscal policy (PF) in Albania, based on a model with four macroeconomic variables, namely: PF , Gross Domestic Product ( GDP ), interest rate and price level. The material was based the method of structural vector autoregression ( SVAR ) and impulses according to the methodology developed by Blanchard and Perrotti (2002 ). The main conclusions of this discussion paper show that FP affects economic activity, the reduction of the burden tax has the highest multiplier cumulative of GDP, and GDP multiplier of capital expenditure is greater than as multiplier for current expenses.

An analysis by Gerti Shijaku and Arlind Gjokuta, experts at the Bank of Albania, focuses on how the composition of expenditure and government revenue impacts of long-term growth rate. The report reaches the conclusion that if the government wants to increase revenue, indirect taxes should be chosen instead to direct taxes, because as they grow, their effect on growth is smaller. On the other hand, while capital expenditure growth has been the biggest positive impact on economic growth and mitigate the effects of the crisis, the survey results show that the value of the coefficient of the debt burden is negatively correlated with the rate of economic growth. Empirical results suggest that since 2007 the link between economic growth and spending is weak, while incomes have greater negative impact on economic growth.

\section{Conclusions}

Fiscal policies are important predictors of economic developments. Often government decisions on spending and taxation play an important role in speeding up or slowing economic growth. By theoretical viewpoints, empirical studies and practical facts position and role of the state in transition economies is considered essential in many transition economies. For Albania, in our opinion an important role in economic performance has also played events inherited from the past. Also the contribution of fiscal policy is very important in stabilizing the main macroeconomic variables, but also for the overall development. If we analyze the issues related specifically in Albania, it is worth mentioning that there is a gap between the quality of regulatory base in fiscal terms, but also in institutional with their implementation in practice. If the government wants to increase revenue, indirect taxes should be chosen instead to direct taxes, because as they grow, their effect on growth is smaller. On the other hand, while capital expenditure growth has been the biggest positive impact on economic growth and mitigate the effects of the crisis, the survey results show that the value of the coefficient of the debt burden is negatively correlated with the rate of economic growth.

\section{References}

OECD (2010), Tax policy reform and economic growth, OECD tax policy studies, no 20

Arnold Jens (2008), Do tax Structures Affect Aggregate Economic Growth? Empirical Evidence from a Panel of OECD Countries, Economic Department Working Paper No 653, ECO/WKP(2008)51, october

North, Douglass C. 1990. Institutions, Institutional Change, and Economic Performance. Cambridge: Cambridge University Press

Sachs, Jeffrey D. 2001. "Tropical Underdevelopment." NBER Working Paper 8119

J.R. Clark and Robert A. Lawson "The Impact of Economic Growth, Tax Policy and Economic Freedom on Income Inequality"

"Growth and Technological Progress: The Solow-Swan Model". The Economics of Adjustment and Growth (Second ed.). Cambridge: Harvard University Press.

Kenneth Arrow (1962) (1962). "The Economic Implications of Learning by Doing". Review of Economic Studies (The Review of Economic Studies)

Paul Romer (1986) "Increasing Returns and Long Run Growth" (Journal of Political Economy, October 1986)

The Lucas (1988) model: Human capital accumulation

Sachs, Jeffrey (2001). The Strategic Significance of Global Inequality (The Washington Quarterly), Vol. 24, No. 3, Summer 2001

Douglass North (1990) Institutions, Institutional Change and Economic Performance, Cambridge University Press, 1990.

Stokey and Rebelo (1995): Growth Effects of Flat-Rate Taxes 
Eric Engen and Jonathan Skinner Fiscal Policy and Economic Growth Ihtsham ul Haq Padda and Naeem Akram: The impact od tx policies on economic growth: Evidence from Asian Economies

Gerti Shijaku and Arlind Gjokuta (2013) : Fiscal policy and economic growth: Case of Albania"

Armela Mancellari (2011) : "Macroeconomic effects of fiscal policy in Albania" 